\title{
Green Marketing to Customer Need and Customer Satisfaction in Herbal City Community: Case of the North of Thailand
}

\author{
Yananda Siraphatthada ${ }^{1} \&$ Duangkamol Thitivesa ${ }^{1}$ \\ ${ }^{1}$ Suan Sunandha Rajabhat University, Bangkok, Thailand \\ Correspondence: Yananda Siraphatthada, Suan Sunandha Rajabhat University, Bangkok, Thailand. E-mail: \\ yananda.si@ssru.ac.th
}

Received: July 17, 2020

Accepted: September 4, 2020

Online Published: September 28, 2020

doi:10.5430/rwe.v11n5p457

URL: https://doi.org/10.5430/rwe.v11n5p457

\begin{abstract}
Herbal medicine companies have essential role among the community. It has unique role in the medicine companies to fulfill the health-related needs of people. However, herbal city community was neglected by the literature. Especially, the role of green marketing was not examined in relation to the customer needs and customer satisfaction. Hence, the current study filled this literature gap by examining the role of green marketing in customer needs and customer satisfaction. This objective was achieved by examining the relationship between green marketing, green environment, customer needs and customer satisfaction. The survey questionnaire was effective tool for data collection which was used in this study and 210 valid responses were used in data analysis. Data were collected from North of Thailand. Results of the study shows that green marketing has positive effect on customer needs. Green marketing also has positive effect on customer satisfaction. Moreover, green marketing promotes green environment which further shows positive influence on customer needs and customer satisfaction.
\end{abstract}

Keywords: green marketing, green environment, customer need, customer satisfaction

\section{Introduction}

To control the environmental disaster, the world is going to promote green environment. Most of the nations in world are working majorly on green environmental performance. As this is one of most suitable way to enhance environmental performance by introducing the concept of green environment. Green environment has significant influence on the performance of environment (Anwar et al., 2020). All the companies are now showing the interest towards green environment because environmental safety is also one of the social responsibilities.

There are number of methods using by the companies to promote green environment. The most vital method is to promote green practices among the companies. Increase in the green practices among all companies has the potential to uplift the green environment which has several advantages. Green marketing practices has vital role among the companies to enhance green environment. Literature also provides several advantages of green environmental (Chen \& Chang, 2013). Especially, green environment has positive role to enhance customer needs. In the recent decade, customers are influencing through environmentally friendly company activities. Better green practices show positive role in customer need and customer satisfaction. Both customer need and customer satisfaction has vital role among the companies (Wahab, Hassan, Shahid, \& Maon, 2016).

Various medicine companies are also moving to adopt green marketing practices. Apart from various pharmaceutical companies, herbal city community also shows the important concern towards environment. Medicine companies in the Thailand has important role in the community. As these companies are the responsible to provide quality medicines. However, the current study is only using herbal city community. Herbal companies are also focusing to produce green product in which these companies are using various envelops which are environmentally friendly. Various companies using various strategies for green marketing. Figure 1 shows that green concept is based on the environment, management theory, new dimensions, ethics and social marketing. The current study is only concerning the environment. 


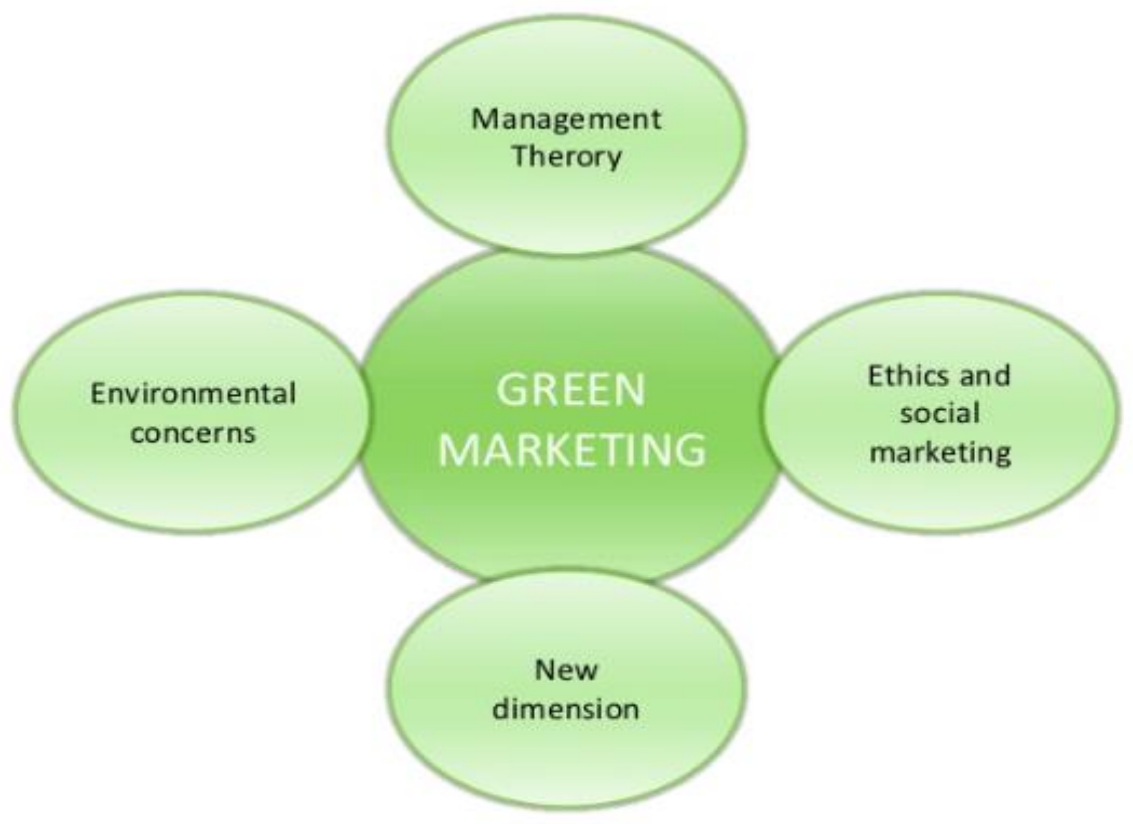

Figure 1. Green building concept

According to the current study, green marketing has vital role in green environment building procedure. Betterment in the green environment has possible role in customer attraction. High quality of environment is one of the attractions for the customers. Therefore, companies better green policy attracts the customers and shows positive effect on customer needs and customer satisfaction. Both customer needs and customer satisfaction has vital role in company performance (Matzler, Bailom, Hinterhuber, Renzl, \& Pichler, 2004). Therefore, objective of this study is to examine the role of green marketing in customer needs and customer satisfaction through green environmental in herbal city community of North Thailand.

Herbal city community was ignored by the literature. Specifically, the role of green marketing was not examined in relation to the customer needs and customer satisfaction. Number of studies are available on medicine companies green practices (Anning \& Haisu, 2020; Attar, Gilaninia, \& Homayounfar, 2016; Austin, 2019; Balakeffi, Oboh, Augustine, \& Fwangkwal, 2019; Ismail, Alawamleh, Aladwan, \& Alragheb, 2019; Kurian, 2018), however, these studies have not consider the herbal community of Thailand. Hence, the current study contributed to the literature and practice by filling the important literature gap.

\section{Literature Review}

With the increase in green practices among the organizations, the effect of green practices on customers is also increasing. Green practices by the organizations has important role in organizations. Various nations in various countries are focusing to increase green practices to support the environment because the environment has major role in human lives. Number of policies are available among the companies to support the environment with the help of green practices. Therefore, it is very important to follow policies of green environment through green practices. Number of studies also recommended the green practices to save the environment (Chang, Chen, Luan, \& Chen, 2019). The extensive stress on green environment also make the customers more conscious about the environment. They are following green practices of various nations as well as various countries. In this direction, it shows positive role on customers. The green practices are the attraction towards customers. Better green practices increase the customer willingness to purchase the product. However, low green practices have negative role among the organizations. Therefore, it is very important to have better green practices by the companies. Now the green practices have influence on the customers' needs and customer satisfaction. Increase in the green practices by the companies increases the customer need and customer satisfaction. It indicates that needs and customer satisfaction can be achieved with the help of green marketing among the herbal city community. It is given in the previous studies that green marketing has positive role in satisfaction of customer (Herath \& Herath, 2019). Better satisfaction has significant in company performance. In the herbal community, it has positive role in product by increasing or 
fulfilling the needs of the customers and increases the herbal city community success. Further to this, green environment also has relationship with customer needs and customer satisfaction (Herath \& Herath, 2019). Environment and customer relationship is very crucial which is given in previous studies (El-Adly \& Eid, 2016). Therefore, Figure 2 shows the relationship between green marketing, green environment, customer level and customer satisfaction.

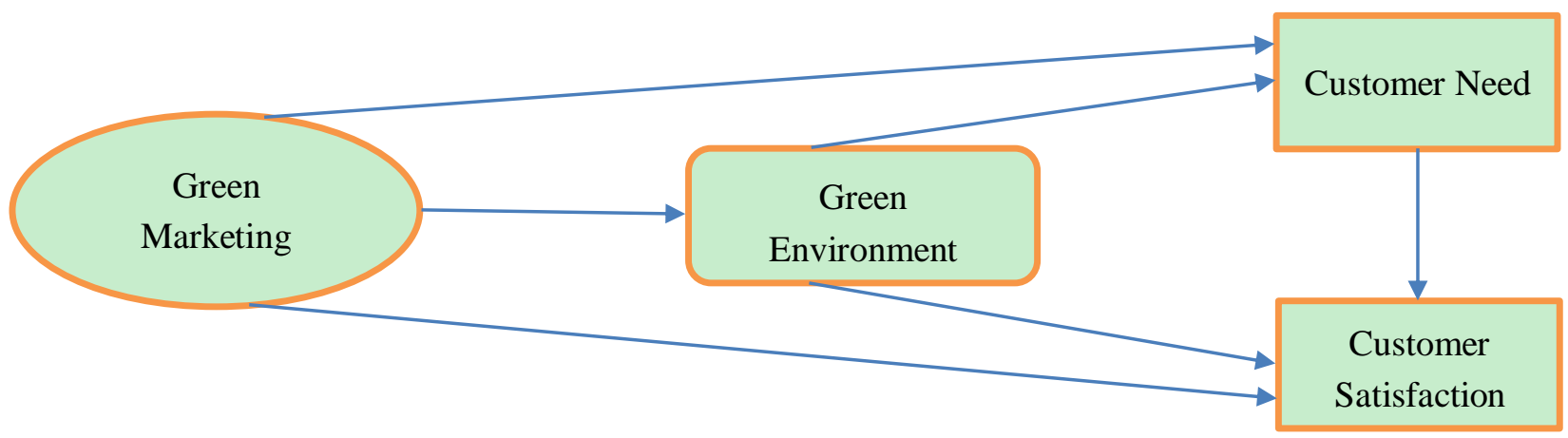

Figure 2. Theoretical framework of the study shows the relationship between green marketing, green environment, customer level and customer satisfaction

\subsection{Green Marketing and Customer Need}

Green marketing is one of the marketing related to the environmentally friendly services or products. It is attractive as well as more prevalent as more people become anxious with environmental issues as well as decide that they desire to devote their money in a way that is kinder to the planet. This concern of green marketing by the companies is increasing. The concern of general people towards the green activities is also increasing which shows relationship with customer need. As in the current environment, customers are also concerned with environment. They also want to purchase environmentally friendly products. That is why the green products are becoming the needs of customers. People are more reluctant to purchase green products. Particularly, those people having high concern to the environment they support those companies which are focusing on green products and these people want to purchase the products of these companies. Therefore, green products are the ultimate needs of customers. In this way, the marketing of green products has relationship with customer needs. Green marketing provides the information's to the customers regarding the green products after getting proper information, people purchase the green products. Therefore, green marketing has central role in customer needs towards green products. The importance of green marketing in relation to the customer is already given in the literature (Buljan \& Zhang, 2020; Cheema, Durrani, Khokhar, \& Pasha, 2015; Sivanandamoorthy, Achchuthan, \& Umanakenan, 2013).

Hypothesis 1. Green marketing has positive effect on customer need.

\subsection{Green Marketing and Customer Satisfaction}

In the herbal community, customer satisfaction is very important for the companies to enhance performance. A stratified customer has significant retention level which causes to repurchase the product form herbal companies. In a competition with the other medicine companies, it is very important for the herbal companies to enhance customer satisfaction. People always want green products from the companies which increases the satisfaction. In this direction, green marketing is a tool to enhance satisfaction among the customers. Development of the herbal companies in respect to the new green products can increase the satisfaction. Herbal community in the North Thailand is lacking to produce new green products which may decrease the customer satisfaction level. It is important because previous studies also show the relationship between marketing and customer satisfaction (Cossiga, 2018; Dai, 2020; Donald, 2019; Ibojo \& Dunmade, 2016; Zakaria, Ahmad, Omar, \& Alhady, 2018).

Hypothesis 2. Green marketing has positive effect on customer satisfaction.

\subsection{Green Marketing and Green Environment}

As shown in above discussion, green marketing has positive influence on customer need. It also has crucial role to enhance customer satisfaction. Moreover, this section shows that green marketing has positive role in green environment. Green Environment narrates to the concerns for environmental conservation as well as better health of the environment. This comprises supportive practices like informed consumption, conservation activities as well as investment in renewable energy. All these environmental practices have positive role to enhance green environment. 
Therefore, green marketing activities shows positive influence on green environment. Green environment has several benefits to the society as it has relationship with the human health and health is the ultimate priority of the nations. All the green activities or practices by the organizations has direct and positive influence on the performance of green environment (Jain, Darbari, Kaul, \& Jha, 2020). The green product development among the herbal medicine companies of Thailand is also important. The medicine prepared by the herbal companies should be environmentally friendly in a sense that the packaging of these medicines should environmentally friendly. Therefore, environment is major concern of the organizations (Solano, Iriarte, Ciria, \& Negro, 2001) in which green marketing is vital.

Hypothesis 3. Green marketing has positive effect on green environment.

\subsection{Green Environment and Customer Need}

Environment is strongly associated with the customer need. As people always required better environment for living. Therefore, along with the organocations, individual people resist to harmful companies to the environment and they always suggest enhancing the green practices. Therefore, green environment is the need of people. It shows that green environment is effect on customer need. In this era of industrialization, the green product awareness forcing companies to enhance green products. Hence, the ultimate requirement of green products from the customer is increasing. The relationship or the effect of green environment has positive role with customer need (Custer, Custer, Allen, Stromborg, \& Melancon, 1998; Ele, 2018; Mann \& Steinke, 1989; Tsai, Chuang, Chao, \& Chang, 2012). Hence, green environment is the most essential part of customer need which is proposed in following hypothesis;

Hypothesis 4. Green environment has positive effect on customer need.

\subsection{Green Environment and Customer Satisfaction}

Customer satisfaction can be explained as a measurement that regulates how happy the customers are with an organizational product, various services, as well as different competences. Customer satisfaction information, counting surveys as well as ratings, can assist an organization determine how to best enhance or changes its products as well as services. Customer satisfaction is the very first concern of the companies because customers are the major contributor of success for the businesses (Agnihotri, Yang, \& Briggs, 2019; Cuevas-Vargas, Parga-Montoya, \& Fernández-Escobedo, 2019; Esenyel, 2020). Customer satisfaction has relationship with green environment. Generally green environment lead to the customer satisfaction. Better green environment practices by the companies shows positive effect on customer satisfaction. Now the organizations are focusing on green environment to enhance customer satisfaction. Especially, in higher competition of medicine companies, green products have major role in performance of the companies. Particularly, it is very significant for herbal city community to compete with other medicine companies. Better green product generation by the herbal companies has the potential to compete with the other medicine companies.

Hypothesis 5. Green environment has positive effect on customer satisfaction.

\subsection{Green Environment as Mediator}

This study used green environment as mediating variables which is proposed with the help of Baron and Kenny (1986) approach. The mediation effect of green environment between green marketing and customer need is well justified as green marketing has significant relationship with green environment and customer need. Green environment has significant relationship with customer need. The significant relationship between these variables shows that green environment can be a mediating variable between green marketing and customer need. On the other hand, the mediating effect of green environment was examined between green marketing and customer satisfaction. Similar to the previous discussed mediation effect, green marketing has significant effect on green environment and customer satisfaction. Green environment has significant relationship with customer need which shows a mediating role of green environment between green marketing and customer satisfaction. Thus, this discussion shows the green environment is a mediating variable between green marketing and customer need. Green environment is also a mediating variable between green marketing and customer satisfaction.

Hypothesis 6. Green environment mediates the relationship between green marketing and customer need.

Hypothesis 7. Green environment mediates the relationship between green marketing and customer satisfaction.

\section{Research Methodology}

This study measured customer need by asking the questionnaires related to the customer essential requirements especially the requirements related to the health. People always require quality medicines to come out from various diseases. Therefore, to measure the customer needs the health needs were considered. Customer satisfaction was measured by asking the questions related to the benefits from the herbal company medicine. As higher the benefit higher will be the customer satisfaction. Green environment was measured by considering various measures related to the green environment practices taken by the herbal medicine companies. Green marketing practices was measured by considering the various green products. Questions in relation to the green products were asked to 
customers related to the herbal companies in North Thailand. Therefore, in line with other studies, this study used quantitative research (Ali, Naveed, ul Hameed, \& Rizvi, 2018; Hamid, Shahid, Hameed, Amin, \& Mehmood, 2019; Razzaq, Maqbool, \& Hameed, 2019).

All the measures were designed in the survey questionnaire. As the survey questionnaire is effective tool for data collection (Bowling, Bond, Jenkinson, \& Lamping, 1999; Ul-Hameed, Mohammad, \& Shahar, 2018). All these measures were designed in Likert scale for data collection. Therefore, survey was conducted among the herbal community as the population of the study was herbal medicine companies of North Thailand. This study is carried out in North Thailand, that is why data were collected from North Thailand herbal community. Moreover, data were collected, and questionnaires were distributed by using the simple random sampling (Siuly, Li, \& Wen, 2011). 400 questionnaires were used in this study and distributed among herbal medicine companies. Finally, 210 questionnaires were used in data analysis. Data were collected through self-visit to the herbal companies and objective of the study was elaborated before data collection. All the questionnaires were distributed and collected in the supervision of researcher. All the returned questionnaires having mistakes in the data were excluded from survey. Moreover, all the questionnaires with missing information was also excluded from the survey. Furthermore, data collected form herbal city community was further analyzed to remove the missing value (Aydin \& ŞENOĞLU, 2018) as well as outlier. Data statistics is given in Table 1.

Table 1. Data statistics

\begin{tabular}{|c|c|c|c|c|c|c|c|c|c|}
\hline & No. & Missing & Mean & Median & Min & Max & SD & Kurtosis & Skewness \\
\hline GM1 & 1 & 0 & 4.847 & 5 & 1 & 7 & 1.854 & -0.674 & -0.565 \\
\hline GM2 & 2 & 0 & 5.274 & 6 & 1 & 7 & 1.752 & -0.446 & -0.792 \\
\hline GM3 & 3 & 0 & 5.363 & 6 & 1 & 7 & 1.815 & 0.289 & -1.119 \\
\hline GM4 & 4 & 0 & 5.008 & 6 & 1 & 7 & 1.803 & -0.585 & -0.681 \\
\hline GM5 & 5 & 0 & 5.016 & 6 & 1 & 7 & 1.943 & -0.745 & -0.658 \\
\hline GM6 & 6 & 0 & 4.895 & 5 & 1 & 7 & 1.731 & -0.687 & -0.507 \\
\hline GM7 & 7 & 0 & 4.839 & 5 & 1 & 7 & 1.928 & -0.932 & -0.534 \\
\hline GM8 & 8 & 0 & 5 & 5 & 1 & 7 & 1.727 & -0.348 & -0.722 \\
\hline GM9 & 9 & 0 & 4.758 & 5 & 1 & 7 & 1.816 & -0.879 & -0.338 \\
\hline GEN1 & 10 & 0 & 4.968 & 5 & 1 & 7 & 1.892 & -0.866 & -0.553 \\
\hline GEN2 & 11 & 0 & 4.758 & 5 & 1 & 7 & 1.851 & -0.905 & -0.335 \\
\hline GEN3 & 12 & 0 & 5.177 & 6 & 1 & 7 & 1.81 & -0.292 & -0.847 \\
\hline GEN4 & 13 & 0 & 5.177 & 6 & 1 & 7 & 1.845 & -0.497 & -0.779 \\
\hline GEN5 & 14 & 0 & 5.081 & 6 & 1 & 7 & 1.762 & -0.332 & -0.813 \\
\hline $\mathrm{CN} 1$ & 15 & 0 & 4.927 & 5 & 1 & 7 & 1.824 & -0.557 & -0.675 \\
\hline $\mathrm{CN} 2$ & 16 & 0 & 4.847 & 5 & 1 & 7 & 1.778 & -0.602 & -0.628 \\
\hline $\mathrm{CN} 3$ & 17 & 0 & 3.952 & 4 & 1 & 7 & 1.946 & -1.178 & 0.228 \\
\hline CN4 & 18 & 0 & 5.242 & 6 & 1 & 7 & 1.618 & 0.235 & -0.885 \\
\hline CN5 & 19 & 0 & 5.097 & 5 & 1 & 7 & 1.739 & -0.608 & -0.579 \\
\hline CN6 & 20 & 0 & 5.29 & 6 & 1 & 7 & 1.726 & -0.003 & -0.896 \\
\hline CS1 & 21 & 0 & 5.25 & 6 & 1 & 7 & 1.716 & -0.484 & -0.764 \\
\hline CS2 & 22 & 0 & 5.298 & 6 & 1 & 7 & 1.75 & 0.102 & -0.969 \\
\hline CS3 & 23 & 0 & 5.129 & 5 & 1 & 7 & 1.665 & -0.292 & -0.674 \\
\hline CS4 & 24 & 0 & 5.008 & 6 & 1 & 7 & 1.847 & -0.6 & -0.688 \\
\hline CS5 & 25 & 0 & 4.032 & 4 & 1 & 7 & 1.862 & -1.119 & 0.173 \\
\hline CS6 & 26 & 0 & 5.032 & 5 & 1 & 7 & 1.84 & -0.774 & -0.48 \\
\hline CS7 & 27 & 0 & 5.194 & 5 & 1 & 7 & 1.804 & -0.522 & -0.703 \\
\hline
\end{tabular}




\section{Data Analysis}

Data analysis was started with Partial Least Square (PLS) (F. Hair Jr, Sarstedt, Hopkins, \& G. Kuppelwieser, 2014; J. F. Hair, Ringle, \& Sarstedt, 2013; Ringle, Wende, \& Will, 2005). Figure 3 was used for confirmatory factor analysis (CFA) in which factor loadings are given. Factor loadings is also given in Table 2. Results of CFA shows that green marketing is measured by using nine items. Green environment is measured through five items. Customer need is measured by using five items and finally, customer satisfaction was measured by using seven items. All these variables have factor loadings above 0.7. As it is recommended that factor loadings should be above 0.7 (J. Hair, Hollingsworth, Randolph, \& Chong, 2017).

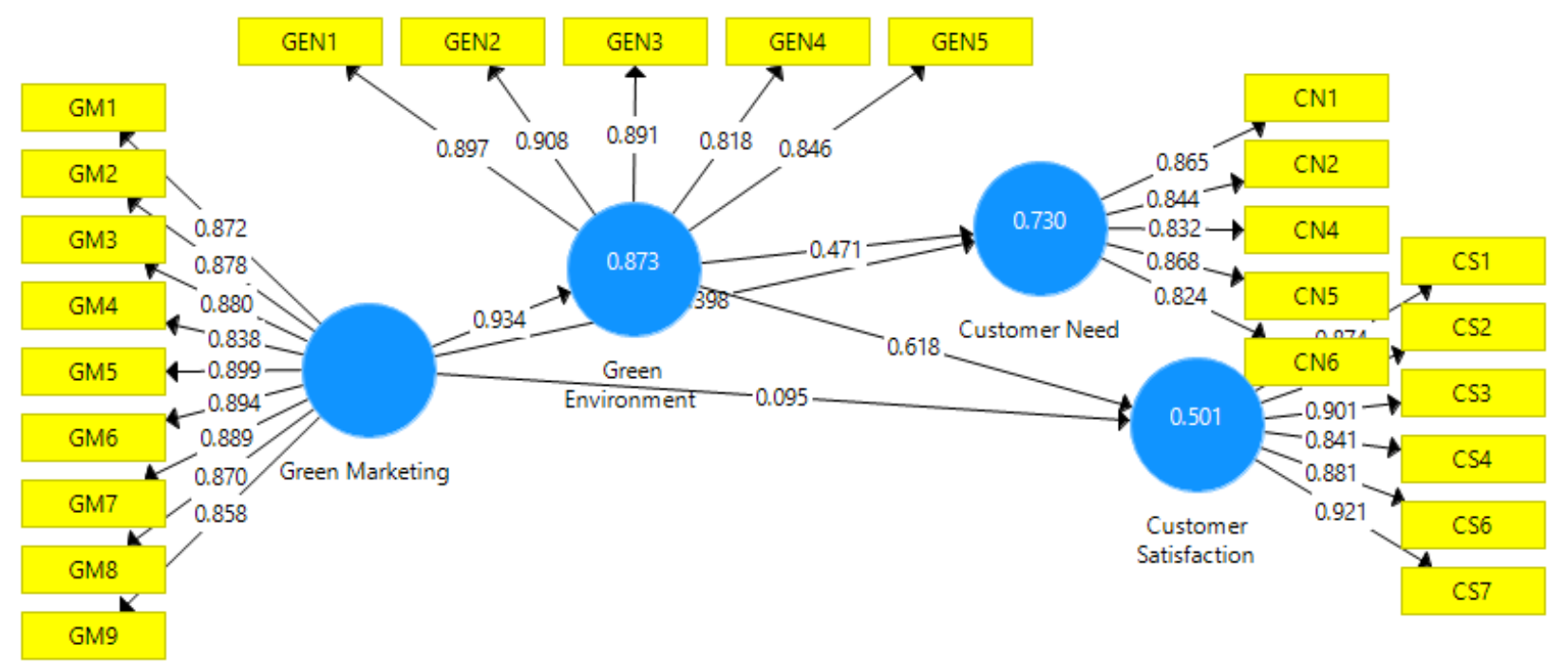

Figure 3. Measurement model

Table 2. Factor loadings

\begin{tabular}{|c|c|c|c|c|}
\hline & $\begin{array}{l}\text { Customer } \\
\text { Need }\end{array}$ & $\begin{array}{l}\text { Customer } \\
\text { Satisfaction }\end{array}$ & $\begin{array}{l}\text { Green } \\
\text { Environment }\end{array}$ & $\begin{array}{l}\text { Green } \\
\text { Marketing }\end{array}$ \\
\hline CN1 & 0.865 & & & \\
\hline $\mathrm{CN} 2$ & 0.844 & & & \\
\hline $\mathrm{CN} 4$ & 0.832 & & & \\
\hline CN5 & 0.868 & & & \\
\hline CN6 & 0.824 & & & \\
\hline CS1 & & 0.874 & & \\
\hline CS2 & & 0.818 & & \\
\hline $\mathrm{CS} 3$ & & 0.901 & & \\
\hline CS4 & & 0.841 & & \\
\hline CS6 & & 0.881 & & \\
\hline CS7 & & 0.921 & & \\
\hline GEN1 & & & 0.897 & \\
\hline GEN2 & & & 0.908 & \\
\hline GEN3 & & & 0.891 & \\
\hline GEN4 & & & 0.818 & \\
\hline GEN5 & & & 0.846 & \\
\hline GM1 & & & & 0.872 \\
\hline
\end{tabular}




\begin{tabular}{lc} 
GM2 & 0.878 \\
GM3 & 0.88 \\
GM4 & 0.838 \\
GM5 & 0.899 \\
GM6 & 0.894 \\
GM7 & 0.889 \\
GM8 & 0.87 \\
GM9 & 0.858 \\
\hline
\end{tabular}

Reliability and convergent validity are given in Table 3 . All the values for reliability and average variance extracted (AVE) must be above 0.7 (J. Hair et al., 2017). It is found that; green marketing, green environment, customer needs and customer satisfaction have reliability above 0.7. It is also found that; green marketing, green environment, customer needs and customer satisfaction have AVE above 0.5 which is given in Table 3 and cross-loadings are given in Table 4.

Table 3. Reliability and convergent validity

\begin{tabular}{lcccc}
\hline & Alpha & rho_A & $\begin{array}{c}\text { Composite } \\
\text { Reliability }\end{array}$ & (AVE) \\
\hline Customer Need & 0.904 & 0.922 & 0.927 & 0.717 \\
Customer Satisfaction & 0.937 & 0.941 & 0.951 & 0.763 \\
Green Environment & 0.921 & 0.923 & 0.941 & 0.762 \\
Green Marketing & 0.962 & 0.963 & 0.967 & 0.766 \\
\hline
\end{tabular}

Table 4. Cross-loadings

\begin{tabular}{lcccc}
\hline & $\begin{array}{c}\text { Customer } \\
\text { Need }\end{array}$ & $\begin{array}{c}\text { Customer } \\
\text { Satisfaction }\end{array}$ & $\begin{array}{c}\text { Green } \\
\text { Environment }\end{array}$ & $\begin{array}{c}\text { Green } \\
\text { Marketing }\end{array}$ \\
\hline CN1 & 0.865 & 0.686 & 0.836 & 0.831 \\
CN2 & 0.894 & 0.619 & 0.856 & 0.842 \\
CN4 & 0.892 & 0.863 & 0.554 & 0.584 \\
CN5 & 0.903 & 0.895 & 0.64 & 0.627 \\
CN6 & 0.924 & 0.771 & 0.569 & 0.559 \\
CS1 & 0.8 & 0.874 & 0.601 & 0.628 \\
CS2 & 0.745 & 0.818 & 0.555 & 0.54 \\
CS3 & 0.778 & 0.901 & 0.644 & 0.615 \\
CS4 & 0.771 & 0.841 & 0.586 & 0.526 \\
CS6 & 0.733 & 0.881 & 0.623 & 0.606 \\
CS7 & 0.813 & 0.921 & 0.687 & 0.607 \\
GEN1 & 0.747 & 0.587 & 0.897 & 0.823 \\
GEN2 & 0.787 & 0.644 & 0.908 & 0.85 \\
GEN3 & 0.741 & 0.649 & 0.891 & 0.845 \\
GEN4 & 0.653 & 0.555 & 0.818 & 0.783 \\
GEN5 & 0.743 & 0.645 & 0.846 & 0.774 \\
GM1 & 0.715 & 0.576 & 0.818 & 0.872 \\
GM2 & 0.76 & 0.61 & 0.799 & 0.878 \\
GM3 & 0.693 & 0.524 & 0.796 & 0.88
\end{tabular}




\begin{tabular}{lcccc} 
GM4 & 0.705 & 0.554 & 0.764 & 0.838 \\
GM5 & 0.811 & 0.662 & 0.864 & 0.899 \\
GM6 & 0.73 & 0.623 & 0.814 & 0.894 \\
GM7 & 0.807 & 0.618 & 0.858 & 0.889 \\
GM8 & 0.667 & 0.542 & 0.795 & 0.87 \\
GM9 & 0.696 & 0.578 & 0.847 & 0.858 \\
\hline
\end{tabular}

Furthermore, the use of structural model was carried out to check the relationship between variables (Henseler \& Chin, 2010; Henseler et al., 2014; Henseler, Ringle, \& Sinkovics, 2009; Ul-Hameed et al., 2018). Results are given in Table 5 and process is given in Figure 5. Direct effect of green marketing was examined on green environment, customer need and customer satisfaction. Direct effect of green marketing was examined on customer need and customer satisfaction. It is found that green marketing has positive effect on green environment, customer need and customer satisfaction. Green environment has positive effect on customer need and customer satisfaction.

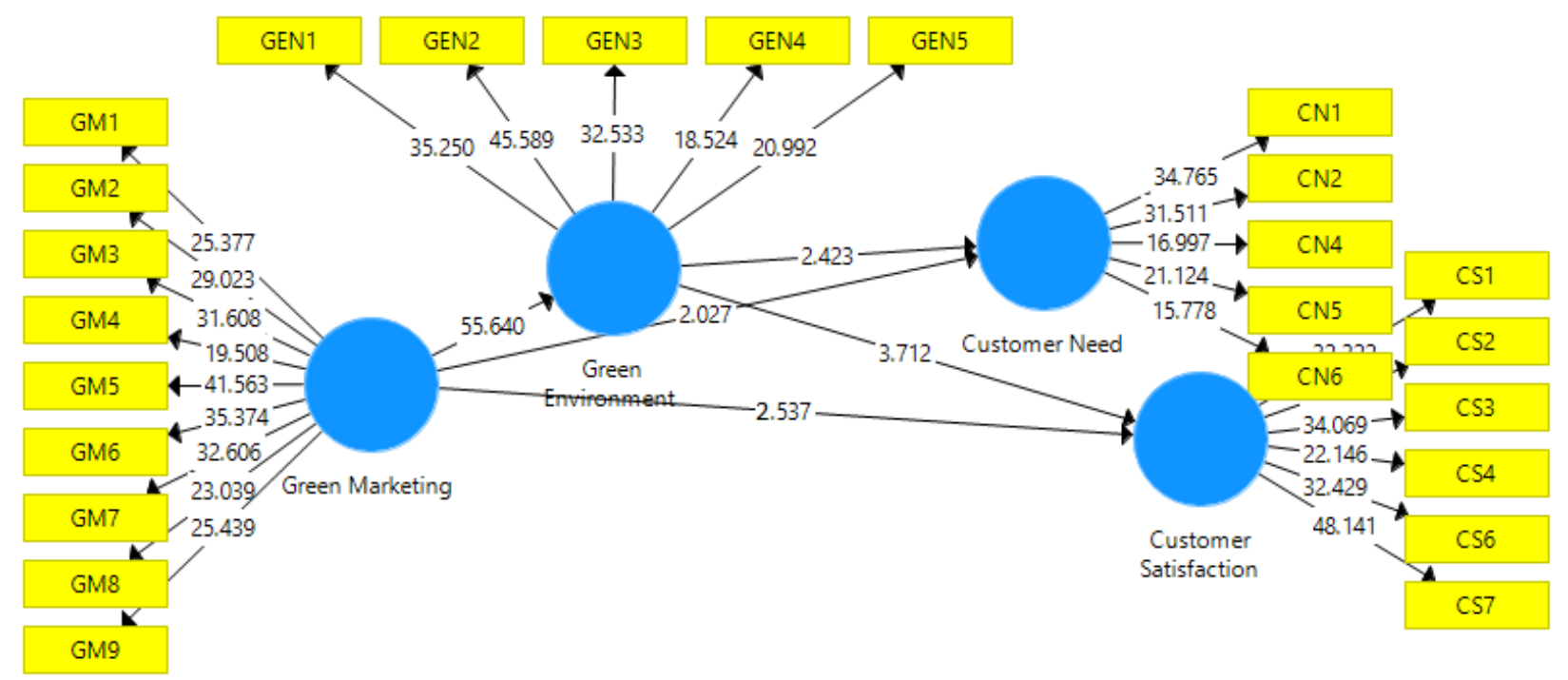

Figure 4. Structural model

Table 5. Direct effect results

\begin{tabular}{lccccc}
\hline & $(\mathbf{O})$ & $(\mathbf{M})$ & SD & T Statistics & P Values \\
\hline Green Environment -> Customer Need & 0.471 & 0.481 & 0.194 & 2.423 & 0.016 \\
Green Environment -> Customer Satisfaction & 0.618 & 0.621 & 0.167 & 3.712 & 0 \\
Green Marketing -> Customer Need & 0.398 & 0.393 & 0.196 & 2.027 & 0.043 \\
Green Marketing -> Customer Satisfaction & 0.095 & 0.098 & 0.038 & 2.537 & 0.008 \\
Green Marketing -> Green Environment & 0.934 & 0.936 & 0.017 & 55.64 & 0 \\
\hline
\end{tabular}

The indirect effect of green environment was examined between green marketing and customer need. The indirect effect of green environment was also examined between green marketing and customer satisfaction. Results in Table 6 shows that indirect effect of green environment between green marketing and customer need is significant with t-value 2.401. The indirect effect of green environment between green marketing and customer satisfaction is also significant with t-value 3.67. The both indirect effect are also given in Figure 5 and Figure 6. Along with this, it is found that r-square value is 0.501 for customer satisfaction which is moderate (Chin, 1998). However, it is strong for customer need which is 0.73 . 
Table 6. Indirect effect results

\begin{tabular}{lccccc}
\hline & & & & T & P \\
& $(\mathbf{O})$ & $(\mathbf{M})$ & SD & Statistics & Values \\
\hline $\begin{array}{l}\text { Green Marketing -> Green Environment -> Customer Need } \\
\text { Green Marketing -> Green Environment -> Customer }\end{array}$ & 0.44 & 0.451 & 0.183 & 2.401 & 0.017 \\
Satisfaction & 0.578 & 0.581 & 0.157 & 3.67 & 0 \\
\hline
\end{tabular}

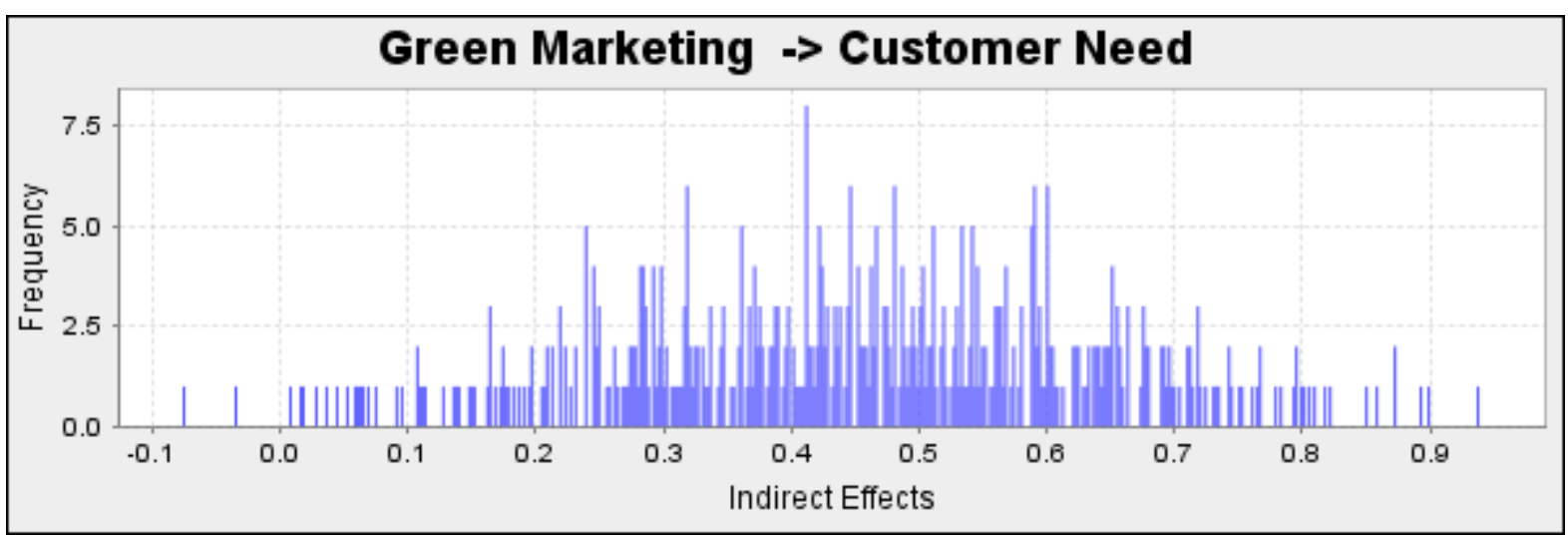

Figure 5. Indirect effect: Green marketing -> Green environment $\rightarrow>$ Customer need

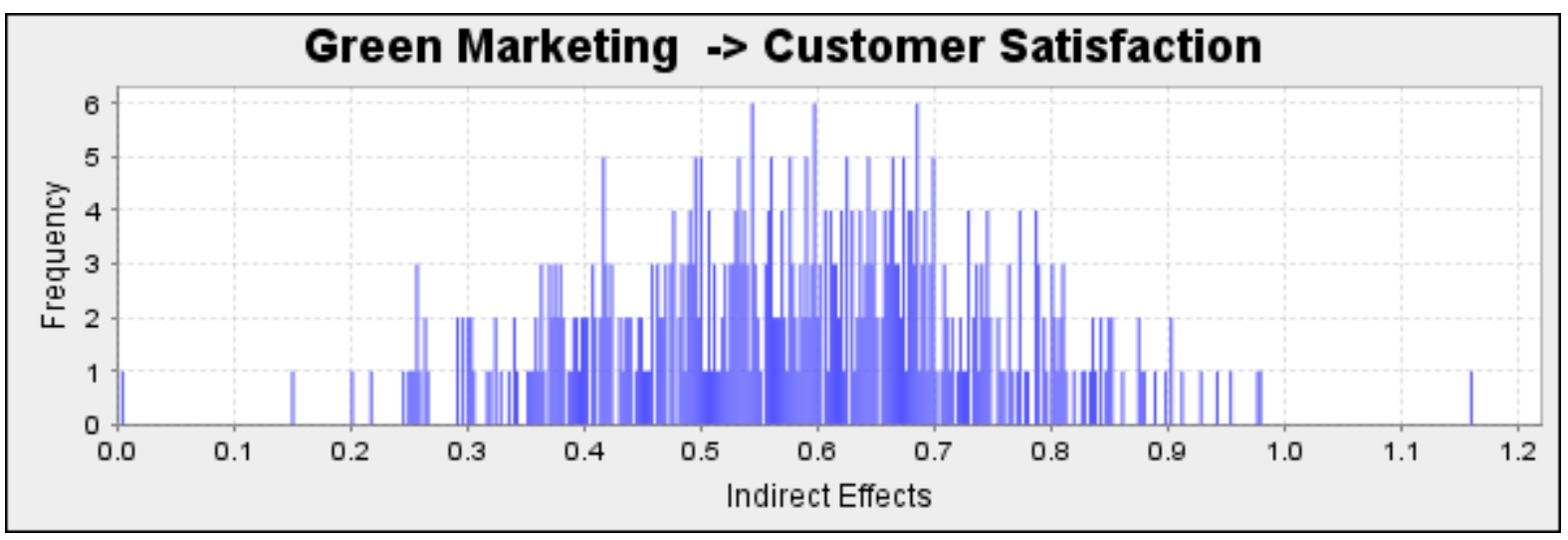

Figure 6. Indirect effect: Green marketing -> Green environment -> Customer satisfaction

\section{Conclusion}

The objective of this study was to examine the role of green marketing in customer needs and customer satisfaction. It was achieved by examining the relationship between green marketing, green environment, customer needs and customer satisfaction. Herbal medicine companies of Thailand were considered in this study. Therefore, this examination was carried out among the herbal city community because previous studies was not examined herbal city community in the context of Thailand. Hence, to fill this literature gap, the effect of green marketing was examined on the green environment, customer needs and customer satisfaction.

Results of the study shows that green marketing has positive effect on customer needs. It is found that increase in the green marketing practices by the companies has positive role to expediate the level of customer needs. It indicates that green marketing increases the customer needs to purchase herbal products as compared to the other products. Green marketing also has positive effect on customer satisfaction. Satisfaction is the major area for herbal companies to compete in the market, therefore, increase in customer satisfaction provide the ability to herbal community to survive in the market. Therefore, to enhance the customer satisfaction, green marketing is important as the current study shows that green marketing has positive effect on customer satisfaction. Thus, green marketing has positive 
effect on both customer needs and customer satisfaction. Moreover, green marketing promotes green environment which further shows positive influence on customer needs and customer satisfaction. It is found that green marketing also has substantial effect to develop green environments. As the environmental concern is the major element among nations, therefore, green practices among herbal companies shows positive role to enhance green environment. Finally, positive role of green marketing lead to the positive effect on customer needs and customer satisfaction. Promotion of green environment through herbal city community has positive influence to promote customer needs and customer satisfaction. The whole results show that; green marketing leads the whole mechanism to promote herbal community customers' needs and customer satisfaction.

\subsection{Implications of the Study}

This study has wider implications for the literature and herbal city community. For the literature, this study examined most unique relationship between green marketing, green environment, customer needs and customer satisfaction which is not examined by the previous studies. Herbal city community was neglected by the literature. Especially, the role of green marketing was not examined in relation to the customer needs and customer satisfaction. That is the reason this study has vital importance for the literature. Especially, this relationship is not considered among the Thai medicine companies. The concept of green marketing in herbal city community of Thailand is first time examined by the current study. Various investigations or various authors argued about the green marketing among herbal community, however, none of the study formally documented the role of green marketing in customer satisfaction and customer needs. Further to this, the vital relationship was examined in this study has significant role for practical purpose. Especially, it is really important for the herbal city community. It is important because this study suggested herbal community to increase customer needs and customer satisfaction with the help of promoting green marketing as well as green environment.

\section{Limitations of the Study}

This study is limited to the herbal city community of Thailand. The herbal medicine companies have difference in each nation. Therefore, in respect to the herbal community, results might be different among other nations. Further studies may conduct to examine the green practices among various other nations in respect to the herbal community. Furthermore, there are many green practices available in the literature. This study only examined the green marketing as single construct. Future studies should include various green marketing practices in a separate way and examine the effect on green environment, customer needs and customer satisfaction.

\section{References}

Agnihotri, R., Yang, Z., \& Briggs, E. (2019). Salesperson time perspectives and customer willingness to pay more: roles of intraorganizational employee navigation, customer satisfaction, and firm innovation climate. Journal of Personal Selling \& Sales Management, 39(2), 138-158.

Ali, G., Naveed, F., ul Hameed, W., \& Rizvi, T. (2018). The Effect of Task Illegitimacy on the Wellness of Employees. UCP Management Review (UCPMR), 2(2), 5-20.

Anning, L., \& Haisu, W. (2020). Journal of Asian business strategy. Journal of Asian Business Strategy, 10(2), 90-113.

Anwar, N., Mahmood, N. H. N., Yusliza, M. Y., Ramayah, T., Faezah, J. N., \& Khalid, W. (2020). Green Human Resource Management for organisational citizenship behaviour towards the environment and environmental performance on a university campus. Journal of Cleaner Production, 256, 120401.

Attar, M., Gilaninia, S., \& Homayounfar, M. (2016). A study of the effect of green supply chain management's components on the performance of the pharmaceutical distribution companies system in iran. Arabian Journal of Business and Management Review (Oman Chapter), 5(8), 48.

Austin, A. (2019). Sectoral credit allocation of deposit money banks and poverty reduction in Nigeria. International Journal of Business, 6(1), 49-60.

Aydin, D., \& Şenoğlu, B. (2018). Estimating the Missing Value in One-Way Anova Under Long-Tailed Symmetric Error Distributions. Sigma: Journal of Engineering \& Natural Sciences/Mühendislik ve Fen Bilimleri Dergisi, $36(2)$.

Balakeffi, L. R., Oboh, V. U., Augustine, U., \& Fwangkwal, M. P. (2019). Uncertainties in global economic policy and nigerias export earnings. International Journal of Business, Economics and Management, 6(1), 23-38.

Baron, R. M., \& Kenny, D. A. (1986). The moderator-mediator variable distinction in social psychological research: Conceptual, strategic, and statistical considerations. Journal of personality and social psychology, 51(6), 1173-1182.

Bowling, A., Bond, M., Jenkinson, C., \& Lamping, D. (1999). Short Form 36 (SF-36) Health Survey questionnaire: 
which normative data should be used? Comparisons between the norms provided by the Omnibus Survey in Britain, the Health Survey for England and the Oxford Healthy Life Survey. Journal of Public Health, 21(3), 255-270.

Buljan, N., \& Zhang, J. H. (2020). The impact of land price movements on the properties in croatia. Journal of Social Economics Research, 7(1), 24-34.

Chang, T.-W., Chen, F.-F., Luan, H.-D., \& Chen, Y.-S. (2019). Effect of green organizational identity, green shared vision, and organizational citizenship behavior for the environment on green product development performance. Sustainability, 11(3), 617.

Cheema, S., Durrani, A. B., Khokhar, M. F., \& Pasha, A. T. (2015). Influence of Green Marketing Mix and Customer Fulfillment: An Empirical Study. International Journal of Sciences: Basic and Applied Research (IJSBAR), 24(6), 168-177.

Chen, Y.-S., \& Chang, C.-H. (2013). Enhance environmental commitments and green intangible assets toward green competitive advantages: an analysis of structural equation modeling (SEM). Quality \& Quantity, 47(1), 529-543.

Chin, W. W. (1998). The partial least squares approach to structural equation modeling. Modern Methods for Business Research, 295(2), 295-336.

Cossiga, G. A. (2018). Signals from the world of economics. The price constant and the democratic issue. International Journal of Social and Administrative Sciences, 3(1), 1-21.

Cuevas-Vargas, H., Parga-Montoya, N., \& Fernández-Escobedo, R. (2019). Effects of entrepreneurial orientation on business performance: The mediating role of customer satisfaction-A formative-Reflective model analysis. SAGE Open, 9(2), 2158244019859088.

Custer, C. M., Custer, T. W., Allen, P. D., Stromborg, K. L., \& Melancon, M. J. (1998). Reproduction and environmental contamination in tree swallows nesting in the Fox River drainage and Green Bay, Wisconsin, USA. Environmental Toxicology and Chemistry: An International Journal, 17(9), 1786-1798.

Dai, J. (2020). Intellectual property rights protection, foreign technology introduction and FDI- based on the provincial-level panel data of China. Journal of Accounting, Business and Finance Research, 8(1), 30-38.

Donald, L. (2019). Satisfaction with applications fuels the growth of mobile wallet use in Thailand. International Journal of Business, 6(1), 16-22.

El-Adly, M. I., \& Eid, R. (2016). An empirical study of the relationship between shopping environment, customer perceived value, satisfaction, and loyalty in the UAE malls context. Journal of Retailing and Consumer Services, $31,217-227$.

Ele, C. O. (2018). Islamization of Nigeria: Implications for sustainable peace. International Journal of Social Sciences and English Literature, 2(1), 13-19.

Esenyel, V. (2020). Corporate reputation as a strategic management tool: Through the lens of employees. International Journal of Management and Sustainability, 9(1), 24-42.

F. Hair Jr, J., Sarstedt, M., Hopkins, L., \& G. Kuppelwieser, V. (2014). Partial least squares structural equation modeling (PLS-SEM) An emerging tool in business research. European Business Review, 26(2), 106-121.

Hair, J., Hollingsworth, C. L., Randolph, A. B., \& Chong, A. Y. L. (2017). An updated and expanded assessment of PLS-SEM in information systems research. Industrial Management \& Data Systems, 117(3), 442-458.

Hair, J. F., Ringle, C. M., \& Sarstedt, M. (2013). Partial least squares structural equation modeling: Rigorous applications, better results and higher acceptance.

Hamid, S. N. A., Shahid, M. N., Hameed, W. U., Amin, M., \& Mehmood, S. (2019). Antecedents Of Job Stress And Its Impact on Nurse's Job Satisfaction and Turnover Intention in Public and Private Hospitals of Punjab Pakistan. International Journal of Scientific \& Technology Research, 8(10), 129-137.

Henseler, J., \& Chin, W. W. (2010). A comparison of approaches for the analysis of interaction effects between latent variables using partial least squares path modeling. Structural Equation Modeling, 17(1), 82-109.

Henseler, J., Dijkstra, T. K., Sarstedt, M., Ringle, C. M., Diamantopoulos, A., Straub, D. W., . . Calantone, R. J. (2014). Common beliefs and reality about PLS: Comments on Rönkkö and Evermann (2013). Organizational Research Methods, 17(2), 182-209.

Henseler, J., Ringle, C. M., \& Sinkovics, R. R. (2009). The use of partial least squares path modeling in international marketing. New challenges to international marketing (pp. 277-319). Emerald Group Publishing Limited. 
Herath, H., \& Herath, H. (2019). Impact of Green Banking Initiatives on Customer Satisfaction: A Conceptual Model of Customer Satisfaction on Green Banking. IOSR Journal of Business and Management (IOSR-JBM), 24-35.

Ibojo, B. O., \& Dunmade, E. O. (2016). Impact of relationship marketing on customer satisfaction: A case study of the undergraduate students in a private university, Oyo State, Nigeria. International Journal of Economics, Commerce and Management, 4(2), 668-708.

Ismail, L. B., Alawamleh, M., Aladwan, K., \& Alragheb, A. A. (2019). The relationship between green SCM practices and organisational performance: evidence from Jordanian pharmaceutical manufacturers. International Journal of Logistics Systems and Management, 34(2), 172-192.

Jain, A., Darbari, J. D., Kaul, A., \& Jha, P. (2020). Selection of a Green Marketing Strategy Using MCDM Under Fuzzy Environment. Soft Computing for Problem Solving (pp. 499-512). Springer.

Kurian, J. (2018). A Study on the Green Supply Chain Management Practices and Their Influence in the Environmental Performance of the Firm: With Reference to Indian Pharmaceutical Industry. OIDA International Journal of Sustainable Development, 11(11), 59-78.

Mann, F. D., \& Steinke, T. (1989). Biological nitrogen fixation (acetylene reduction) associated with blue-green algal (cyanobacterial) communities in the Beachwood Mangrove Nature Reserve. I. The effect of environmental factors on acetylene reduction activity. South African Journal of Botany, 55(4), 438-446.

Matzler, K., Bailom, F., Hinterhuber, H. H., Renzl, B., \& Pichler, J. (2004). The asymmetric relationship between attribute-level performance and overall customer satisfaction: a reconsideration of the importance-performance analysis. Industrial marketing management, 33(4), 271-277.

Razzaq, S., Maqbool, N., \& Hameed, W. U. (2019). Factors Effecting The Elasticity Of Micro Credit Demand In Southern Punjab, Pakistan. International Journal of Social Sciences and Economic Review, 1(2), 46-53.

Ringle, C., Wende, S., \& Will, A. (2005). SmartPLS 2.0 (beta). University of Hamburg, Hamburg, Germany. Computer software downloaded. Retrieved from http://www.smartpls.de

Siuly, Li, Y., \& Wen, P. (2011). EEG signal classification based on simple random sampling technique with least square support vector machine. International journal of Biomedical Engineering and Technology, 7(4), 390-409.

Sivanandamoorthy, S., Achchuthan, S., \& Umanakenan, R. (2013). Green Marketing practices and customer satisfaction: A special Reference to leather goods.

Sivesan, S, Achchuthan, S., \& Umanakenan, R (2013), Green Marketing Practices and Customer Satisfaction: A Special Reference to Leather Goods. Global Journal of Management and Business Research Accounting and Auditing, 13(3), 51-59.

Solano, M., Iriarte, F., Ciria, P., \& Negro, M. (2001). SE—-structure and environment: performance characteristics of three aeration systems in the composting of sheep manure and straw. Journal of Agricultural Engineering Research, 79(3), 317-329.

Tsai, M.-T., Chuang, L.-M., Chao, S.-T., \& Chang, H.-P. (2012). The effects assessment of firm environmental strategy and customer environmental conscious on green product development. Environmental Monitoring and Assessment, 184(7), 4435-4447.

Ul-Hameed, W., Mohammad, H., \& Shahar, H. (2018). Microfinance institute's non-financial services and women-empowerment: The role of vulnerability. Management Science Letters, 8(10), 1103-1116.

Wahab, N. A., Hassan, L. F. A., Shahid, S. A. M., \& Maon, S. N. (2016). The relationship between marketing mix and customer loyalty in hijab industry: The mediating effect of customer satisfaction. Procedia Economics and Finance, 37, 366-371.

Zakaria, A., Ahmad, S. S., Omar, M. W., \& Alhady, S. M. A. S. A. (2018). The Effect Of Relationship Marketing, Customer Satisfaction And Service Quality Towards Customer Loyalty: A Case Study In XYZ SDN BHD. International Journal of Accounting, 3(11), 98-104.

\section{Copyrights}

Copyright for this article is retained by the author(s), with first publication rights granted to the journal.

This is an open-access article distributed under the terms and conditions of the Creative Commons Attribution license (http://creativecommons.org/licenses/by/4.0/). 